\title{
The European Association for Bronchology and Interventional Pulmonology Is in Mourning
}

Chris T. Bolliger passed away untimely and inconceivably on November 2, 2012. Not only The Community of Interventional Pulmonology but also that of Pulmonology around the world has lost one of the invaluable pioneers and leaders in the field.

He was as an excellent scientist, clinician and counselor, a tireless mentor, a great friend and a person who enjoyed his life fully together with his family.

In 2002, he was one of the founders of our society and served enthusiastically for all the years at the board of directors. From 2006 to 2012, he was the president of the society. During this time, he worked hard to develop a small society from the scientific community. Nowadays, the European Association for Bronchology and Interventional Pulmonology (EABIP) has become one of the big players in the field.

In addition to all his activities as a medical doctor, scientist, lecturer and mentor, he improved Respiration, the journal of the EABIP and made it one of the leading journals in Pulmonology.
His untimely death did not befit his young mind and soul with endless energy and enthusiasm. We are deeply sad and in shock and will miss him so much ...

But we will never forget him and his achievements by carrying them to a higher level that he would love to see.

We send our cordial condolences, concerns and sympathies to his family and wish them much strength, endurance and a lot of support for the upcoming time.

In memory of Chris with love, friendship and respect, his EABIP friends,

Felix Herth

Hervé Dutau

Stefano Gasparini

Semra Bilaceroglu

Paola Gasche

Syed Arshad Husain

\section{KARGER}

(C) 2012 S. Karger AG, Basel

Fax +41613061234

E-Mail karger@karger.ch

www.karger.com 